\title{
Experimental Analysis of Light Weight Concrete
}

\author{
R. Aisswarya \\ P.G. Scholar, Dept. of Civil Engineering \\ Veltech HighTech Engineering College \\ Avadi, Chennai \\ India
}

\begin{abstract}
Background/Objectives: Lightweight concrete is widely accepted due to its low density. LECA is an artificial lightweight aggregate made of clay having very low specific gravity. It is possible to develop lightweight concrete using LECA with a dry density of $1200 \mathrm{~kg} / \mathrm{m} 3$ up to $1450 \mathrm{~kg} / \mathrm{m} 3$.

The significance of lightweight concrete is reduced mass and improved thermal and sound insulation properties while maintaining adequate strength. These properties of lightweight concrete depend on the properties of lightweight aggregate (LECA). For developing lightweight concrete of required strength and properties the different engineering properties of LECA has to be studied.

Methods/Statistical analysis: The different special properties mentioned for LECA lightweight concrete opens a wide applicability in the concrete industry and in structural members. For acceptance of concrete as structural concrete, it must possess sufficient resistance to repeated loading (cycling loading) which is predominant during the earthquake. The concrete cubes are casted with the nominal mix, 10\%, 20\%, 30\%, 40\% and 50\% replacement of coarse aggregate by LECA and the acceptable characteristic strength attaining for the mix is calculated and the slabs are casted with the respective mix.

Findings: The cyclic loading can be stimulated in the laboratory using a loading frame and hydraulic jack with sufficient setup. Using such a setup the cyclic behavior of lightweight concrete slabs as well as control composite slabs can be studied. These test results can be used to suggest methods to develop structural lightweight concrete with desirable properties.
\end{abstract}

.Keywords: Cyclic loading, lightweight aggregate, lightweight concrete, repeated loading.

\section{INTRODUCTION}

Concrete is the second largest used material in the world. Since the invention of Portland cement by Joseph Asphdin, the development of concrete and its industry begins. The significance of concrete such as strength, durability, mass production and mould ability made it reliable and acceptable in construction industry. The introduction of different materials in and apart from its ingredients makes it possible to produce different species in concrete.

Concrete has its own nature of its mass and density. As considering its density, it has a dry density of $2400 \mathrm{~kg} / \mathrm{m} 3$. This selfweight of concrete restricts the designer to provide extra steel to compensate its self-weight. This can be effectively encountered by developing lightweight concrete. ${ }^{1,2}$

\subsection{Light Weight Concrete}

Concrete having an over-dry density range of approximately 300 to a maximum of $2000 \mathrm{~kg} / \mathrm{m} 3$, with corresponding cube strengths from approximately 1 to over $60 \mathrm{MPa}$ and thermal conductivities of 0.2 to $1.0 \mathrm{~W} / \mathrm{Mk}$ are considered as light weight concrete. ${ }^{3,4,5}$ These values can be compared with those for normal weight concrete of approximately $2100-2500 \mathrm{~kg} / \mathrm{m} 3,1.5 \mathrm{greater}$ than $100 \mathrm{MPa}$ and 1.6-1.9 W/mK. The principle techniques used for producing lightweight concrete can be summarized as follows :

1. Omitting the finer fraction of normal weight aggregate to create air-filled voids using a process pioneered by Wimpey in the UK in 1924 (no-fibes concrete).

2. Including bubbles of as in a cement paste or mortar matrix to form a cellular structure containing approximately $30-50$ per cent voids (aerated or formed concrete)

3. Replacing, either wholly or partially, natural aggregates in a concrete mix with aggregates containing a large proportion of voids (lightweight aggregate concretes). 


\subsection{Classification Of Light Weight Concrete}

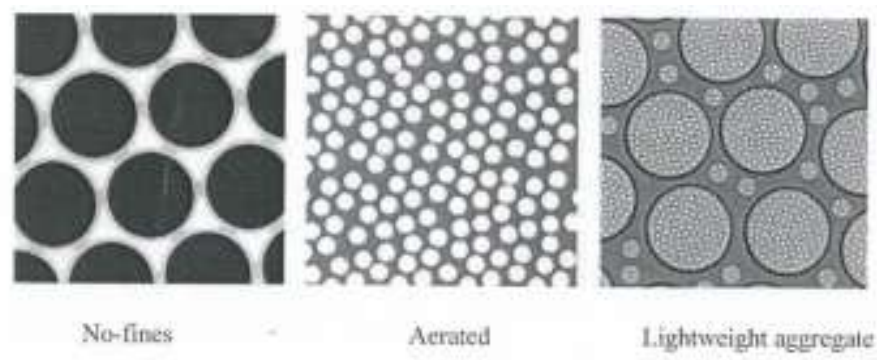

Figure . Types of Light Weight Aggregate

\section{No-fines concrete}

It is a mix of cement, water and coarse aggregate with fines (sand) omitted. This result in each particle of coarse aggregate is coated with a layer (up to about $1.3 \mathrm{~mm}$ ) of cement paste which bonds it to adjacent particles in point to point contact to leave interstitial voids. In non-fines aggregate concrete the voids are interconnected to produce a porous open textured concrete the reduced density, strength and shrinkage. Maximum aggregate size can range from 7 to $75 \mathrm{~mm}$ but is usually from 10 to $20 \mathrm{~mm}$. For normal weight aggregates, aggregate/cement ratios from 6 to 10 produce densities of between 1200 and $1900 \mathrm{~kg} / \mathrm{m}^{3}$.

\section{Aerated and foamed concrete}

Aerated concrete containing intentionally entertained voids in the hardened cement paste or mortar matrix to form a cellulose structure of low density are known as aerated cellular, gas, foamed or foam concretes. They are divided into two principle types namely aerated and foamed. The air can be introduced into a mortar or concrete mix using two principle methods. First, using first using foam generator and second, a synthetic or protein based foam producing admixture mixed with other constituents in a normal mixer or high-shear mixer. The resulting bubbles in the hardened concrete should be discrete and usual bubble size is between 0.1 and $1 \mathrm{~mm}$.

\section{Light Weight Concrete}

The variety purpose of lightweight aggregate concrete is recognized by RILEM and classified as per (RILEM, 1978$) 21$.

\section{Classification of lightweight concrete}

Table 1: Properties of LECA

\begin{tabular}{|c|c|c|c|}
\hline \multirow{2}{*}{ Properties } & \multicolumn{3}{|c|}{ Class and Type } \\
\cline { 2 - 4 } & $\begin{array}{c}\text { I } \\
\text { Structural }\end{array}$ & $\begin{array}{c}\text { II } \\
\text { Structural } \\
/ \text { Insulating }\end{array}$ & $\begin{array}{c}\text { III } \\
\text { Structural }\end{array}$ \\
\hline $\begin{array}{c}\text { Compressive Strength } \\
(\mathrm{MPa})\end{array}$ & $>15$ & $>3.5$ & $>0.5$ \\
\hline $\begin{array}{c}\text { Coefficient of thermal } \\
\text { expansion (W/Mk) }\end{array}$ & - & $<0.75$ & $<0.3$ \\
\hline $\begin{array}{c}\text { Approximate density } \\
\left(\mathrm{Kg} / \mathrm{m}^{3}\right)\end{array}$ & $1600-2000$ & $<1600$ & $<1450$ \\
\hline
\end{tabular}

Natural light weight aggregate include Pumice, diatomite, scoria, volcanic, sawdust, rice husk. Artificial aggregates include artificial cinders, coke breeze, foamed slag, thermacoal beads, LECA.

\section{LECA LIGHT WEIGHT AGGREGATE CONCRETE}

Light weight concrete can be made from LECA as coarse aggregate. They are light enough and their lightness is due to the porosity present in the material by heating the clay to the temperature of 1300 degrees. In the heating process, the wet clay starts to expand by having porous inside and hence the LECA becomes light in weight.

\section{WORLDWIDE ACCEPTANCE OF LIGHT WEIGHT CONCRETE}

Structural light weight concrete is defined as a concrete with an oven dry density of no greater than $2000 \mathrm{~kg} / \mathrm{m}^{3}$ there are variations in certain parts of the world. For example, in Australia structural light weight concrete is considered to be a concrete made with light weight coarse aggregate and normal weight fines resulting in a saturated surface-dry density of not less than $1800 \mathrm{~kg} / \mathrm{m}^{3} . \mathrm{In}$ 
the USA structural lightweight aggregate concrete is considered to be an concrete with air dry density of less than $1810 \mathrm{~kg} / \mathrm{m}^{3} . \mathrm{In}$ Russia lightweight concrete is defined in terms of its compressive strength.

\section{NEED FOR DEVELOPMENT OF LIGHTWEIGHT CONCRETE}

a. Low Density: It can be used to reduce the self-weight of structure.

b. Compressive Strength: It can be effectively use in structural components.

c. Low Thermal Conductivity Concrete: The lower thermal conductivity of LECA provides less heat loss. LECA has 4 times the R-Value of typical sand and gravel aggregate concrete. This significant R-Value increase both slow heat transfer and eliminates or reduces moisture condensation on walls and ceilings.

d. Workability, Appearance, Acoustics: Workability particularly in nailing, sawing and drilling, Acoustic ranges are high.

The repairing and strengthening processes are aims to improve the performance of the concrete members, restore and increase the strength and stiffness of the concrete, improve the appearance of the concrete surface, increase water tightness, prevent access of corrosive materials to the reinforcing, and improve the overall durability of the concrete members.

\section{METHODOLOGY}

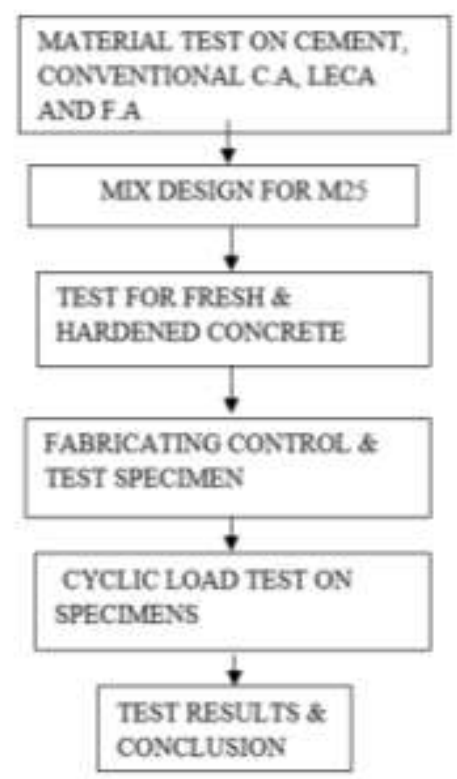

Figure. 2 Methodology chart

\subsection{Material Specification}

i. Cement : Ordinary Portland cement, 53 grade conforming to IS : $12269-2013$

ii. Fine Aggregate : Locally available river sand conforming to grading zone II of

iii. Natural Coarse Aggregate : Locally available crushed blue granite stones conforming to grade aggregate of nominl size 20mm as per IS $383-1970^{10}$

iv. LECA : Manufactured from Future Farms , Velacherry.

\subsection{Material Testing}

\section{Cement}

i. Specific gravity test : Specific gravity test as per IS: 2720 - Part 3 was conducted.

ii. Standard Consistency Test : To find specific gravity, as per IS: $4031-1988$ \& standard consistency was found to be $38 \%$.

iii. Setting time of cement : Initial \& final setting time is found out as per IS 122691987 Specifications.

Initial setting time : $95 \mathrm{~min}$

Final setting time : $345 \mathrm{~min}^{9}$

iv. Compressive Strength : Test is conducted based on IS $12269-1987^{9}$. Average compressive strength of cube mortar at 28 days is obtained as $58.3 \mathrm{~N} / \mathrm{mm}^{2}$

\section{Fine aggregate}

Clean and dry sand available locally will be used sand passing through IS4.75mm sieve will be used for casting all the specimens. The following experiment were conducted to find out the properties of F.A as per IS-2386

i. Specific gravity test : The specific gravity is found to be 2.36

ii. Sieve analysis : The fineness modulus value is calculated as 2.75 .

iii. Water absorption test: The water absorption is found to be $0.917 \%$

\section{Coarse aggregate}




\section{R. Aisswarya et. al., Experimental analysis of light weight concrete}

The following experiment were conducted on normal coarse aggregate and light weight expanded clay coarse aggregate to find out the properties of coarse aggregate as per IS-2386:1963 ${ }^{11,12}$.

i.Specific gravity test: The specific gravity for ordinary coarse aggregate is calculated as 2.67 and for pumice coarse aggregate is 0.44 .

ii. Water absorption test: The water absorption for ordinary coarse aggregate is found as $1.1 \%$

iii. Sieve analysis: The fineness modulus for quarry coarse aggregate $=7.27 .{ }^{12,11}$

iv. Impact test: the impact strength of normal coarse aggregate as $7.29 \%$

\section{Steel}

The steel reinforcing bars of Fe415 grade are tested under universal 1786:2008. The test results are represent in the table below.

Table 2: Property of Steel

\begin{tabular}{|c|c|}
\hline Yield tensile strength & $481 \mathrm{~N} / \mathrm{mm}^{2}$ \\
\hline Ultimate tensile strength & $552 \mathrm{~N} / \mathrm{mm}^{2}$ \\
\hline
\end{tabular}

\section{Water}

Casting and curing of specimen were done with the potable water. Water is used for both mixing and curing shall be clean and the amounts of deleterious material and such as oil, acids, alkalis, salts, sugar, organic material or other substance that may be deleterious to concrete or steel.

\section{Mix Design}

\section{General}

The process of selecting suitable ingredients of concrete and determining their relative amounts with the objective of producing a concrete of the required strength, durability and workability as economically as possible is termed the concrete mix design

\section{Mix design for M25 grade concrete}

The mix design for obtaining the amount of cement, fine aggregate and coarse aggregate are calculated based upon the code IS 10269:2009.Finally derived mix proportion is as follows. ${ }^{13}$

$\begin{array}{lllll}\text { Cement } & \text { Water } & \text { F.A } & \text { C.A } & \text { W/C ratio } \\ 480 \mathrm{~kg} / \mathrm{m}^{3} & 192 \mathrm{~kg} / \mathrm{m}^{3} & 576 \mathrm{~kg} / \mathrm{m}^{3} & 1100 \mathrm{~kg} / \mathrm{m}^{3} & 0.40\end{array}$

To expression the proportion in the usual way

$\begin{array}{ccccc}\text { Cement } & : & \text { FA } & : & \text { CA } \\ 1 & : & 1.2 & : & 2.29\end{array}$

\section{CONTROL AND LIGHT WEIGHT CONCRETE.}

For a comparative study M25 grade concrete is chosen as concrete. The control is worked out design mix with 1:1.2:2.29 with a $\mathrm{W} / \mathrm{C}$ ratio of 0.4.Light weight concrete is produced by complete replacement of coarse aggregate with LECA coarse aggregate in derived M25 mix..$^{10,11,12}$ Expanded clay aggregate is crushed and dressed to $20 \mathrm{~mm}$ aggregate. Due to high water absorption property of LECA lightweight aggregate pre-wetting of aggregate is done prior to concreting. 24 hours of wetted aggregate is taken out and water is wiped out. The ingredients are mixed with water thoroughly to get a uniform mixture. The fresh and hardened properties of concrete are important due to their influence in performance of concrete as a load bearing member.

\section{Fresh concrete properties}

\section{SLUMP CONE TEST}

The concrete slump test is an empirical test that measures the workability of fresh concrete. It measures the consistency of the concrete in that specific batch. This test is performed to check the consistency of freshly made concrete.

\section{Slump value for fresh control and LWC}

Table 3: Slump Value for $L W$ concrete and Control concrete

\begin{tabular}{|c|c|c|l|c|l|}
\hline \multirow{2}{*}{ TRAIL } & \multirow{2}{*}{$\begin{array}{c}\text { Standard } \\
\text { Diameter } \\
\end{array}$} & \multicolumn{2}{|c|}{ Control concrete } & \multicolumn{2}{c|}{ LW Concrete } \\
\cline { 3 - 6 } & & Spread dia in cm & Flow\% & Spread dia in cm & Flow\% \\
\hline 1 & 30 & 31.2 & 24.8 & 33 & 32 \\
\hline 2 & 30 & 31.6 & 26.4 & 32.7 & 30.8 \\
\hline 3 & 30 & 32 & 28 & 32.9 & 31.6 \\
\hline AVG & 30 & $26.4 \%$ & \multicolumn{2}{c|}{$31.5 \%$} \\
\hline
\end{tabular}




\section{HARDENED CONCRETE PROPERTIES}

\section{Casting of Concrete}

The six concrete cubes and cylinder specimens are casted for tests conducted at 7 and 28 days. For casting cube specimen cube moulds of size $150 \times 150 \times 150$ and for cylinder $15 \mathrm{~mm}$ dia $^{8}$. And $30 \mathrm{~mm}$ high cylindrical moulds are used. The inner surface was thoroughly cleaned and a thin layer of grease was coated. The concrete was filled and compacted to three layers with standard tampering bar and after the top layer was compacted, the surface of the concrete was finished in level with top of the mould using a trowel.

\section{Compressive strength test :}

The strength of concrete cubes are tested after 7 and 28 days. It is done as per IS $516: 1959$. The compressive strength should not be less than $25 \mathrm{~N} / \mathrm{mm}^{2}$.

\section{Cylinder split tensile strength test}

The test is conducted at $7^{\text {th }}$ and $28^{\text {th }}$ day. It is done as per IS $456: 2000$ and IS $5816: 1999$. The split tensile strength of the concrete should not be less than $1 / 10$ of $\mathrm{f}_{\text {ck }}$.

\section{TEST RESULTS}

Table 4 TEST RESULTS

\begin{tabular}{|c|c|c|}
\hline SPECIMEN & $\begin{array}{c}\text { COMPRESSIVE } \\
\text { STRENGTH }\end{array}$ & $\begin{array}{c}\text { SPLIT } \\
\text { TENSILE } \\
\text { STRENGTH }\end{array}$ \\
\hline Nominal & 40.75 & 3.95 \\
\hline 10\% Replacement & 37.5 & 3.35 \\
\hline 20\% Replacement & 35.53 & 3.15 \\
\hline 30\% Replacement & 32.35 & 2.84 \\
\hline 40\%Replacement & 24.73 & 2.24 \\
\hline
\end{tabular}

\section{TESTING OF COMPOSITE SLAB UNDER CYCLIC ROAD \\ Composite slab}

A slab is a structural element capable of withstanding load primarily by resisting bending. The simply supported slab is the simplest case for analysis. The flexural and shear capacity of slab depends on provided cross sectional dimensional, longitudinal reinforcement, shear reinforcement and type of loading ${ }^{1,14,2,4,3}$. Two point loading is commonly applied loading experimental studies. The equidistant load applied from both sides at a distance $\mathrm{L}_{\mathrm{e}} / 3$ distance from the support avoid stress concentration and spreads applied load. ${ }^{8,7}$

\section{Cyclic load}

Cyclic loading is a time dependent fluctuating load with loading and unloading cycles. It induces cyclic stress and fatigue in members this type of loading is characteristic of earthquake vibrations and predominant in bridge decks. The fatigue and cyclic stresses induces nonlinear behaviour which adversely affects loading carrying capacity of structural member. ${ }^{67,8}$

\section{Design of Composite Slab}

A slab of size 1250x600x100mm is adopted for laboratory testing. The Re-entrant profiled composite slabs are used as main reinforcement. The slabs are designed as one way slab. The overhanging distance on either side is taken as $100 \mathrm{~mm}$.The effective span of the slab is $1050 \mathrm{~mm}$.A minimum of $8 \mathrm{~mm}$ dia bars at $230 \mathrm{~mm}$ center to center is provided at the distance of $25 \mathrm{~mm}$ from the top to take care of Thermal and Shrinkage cracks.

\section{CASTING OF COMPOSITE SLAB SPECIMEN:}

Two light weight concrete slabs are scheduled for testing. Bars bending of reinforcement was done for secondary reinforcement The prepared reinforcement gauges are laid in position inside the mould. The ingredients for control concrete is weight batched based on mix ratio and uniform mix mixer machine is used and compacted into two layers using standard tamping rod. Then the concrete is trowel finished kept for setting and cured for 28 days .The same procedure for casting and curing of control mix is followed for light weight concrete also.

\section{TESTING OF SPECIMEN}

\section{Test set up :}

Cyclic loadings are stimulated on slab specimen using loadings frame and 100T capacity hydraulic jack. Force for loadings is derived from the reactions between horizontal slab in loading frame and supports. The applied load is accurately measured with a $100 \mathrm{~T}$ capacity proving ring mounted in between loading frame and hydraulic jack. The deflection occurs as a result of loading is measured with a dial gauge of $0.002 \mathrm{~mm}$ accuracy. 


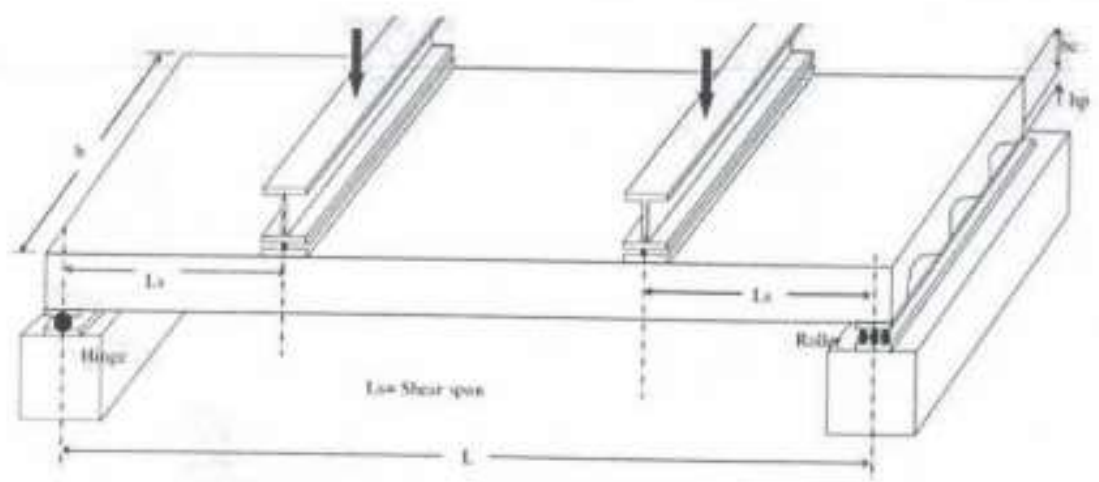

Figure 3 TEST SET UP

\section{Test procedure}

Cyclic loading a type of fluctuating loading is stimulated applied and controlled by the entire loading setup. The governing parameter is resultant displacement in which the displacement is controlled to measure the force applied. The expected deflection is divided into seven cycles. In each cycle three numbers of repetitions for same set of loads are applied. Cyclic loading is stimulated by applying maximum load in each cycle as step by step.

The load and deflection corresponds to loading and unloading are noted. The loading procedure is continued till the entire sets of cycles are completed the load vs deflection curve is plotted.

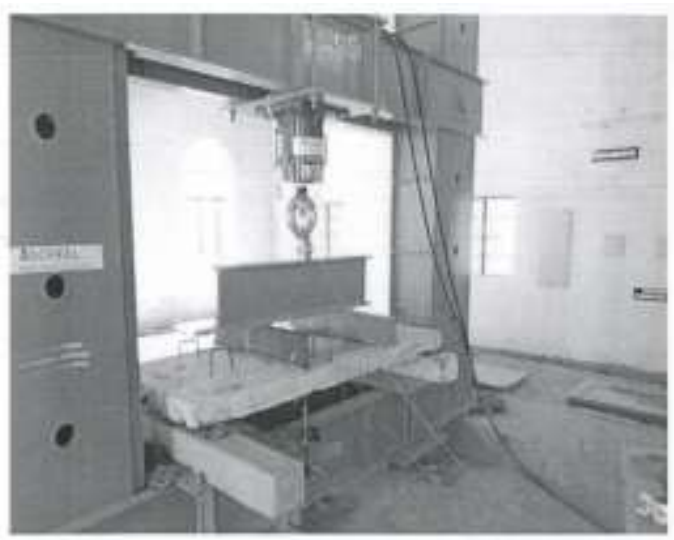

Fig 4 Loading of Slab in Loading Frame

MATERIAL TEST RESULTS

Table 6 Comparison between experimental an limiting Value

\begin{tabular}{|l|l|c|c|}
\hline S.N & \multicolumn{1}{|c|}{ Property } & $\begin{array}{c}\text { Experimental } \\
\text { Value }\end{array}$ & \multicolumn{1}{c|}{ Limiting Value } \\
\hline 1 & Specific gravity of cement & 3.17 & 3.15 \\
\hline 2 & Standard consistency of cement & $32 \%$ & $33 \%$ \\
\hline 3 & Initial setting time of cement & $95 \mathrm{~min}$ & IS 12269-1987 not<30min clause 5.3 \\
\hline 4 & Final setting time of cement & $345 \mathrm{~min}$ & IS 12269-1987 not $>600 \mathrm{~m}$ in clause 5.3 \\
\hline 5 & $\begin{array}{l}\text { Average compressive strength test } \\
\text { of cement mortar cube 28 days }\end{array}$ & $58.3 \mathrm{~N} / \mathrm{mm}^{2}$ & $\begin{array}{l}\text { Not<53 N/mm } \\
\text { as per IS } 12269-1987\end{array}$ \\
\hline 6 & Specific gravity of F.A & 2.68 & $2.6-2.7$ \\
\hline 7 & Sieve anaylsis of F.A & FM=2.75 & Medium sand 2.6-2.9 \\
\hline 8 & Water absorption test on F.A & $0.971 \%$ & $<2 \%$ \\
\hline 9 & Specific gravity test for C.A & 2.67 & Approximate C.A 2.7 \\
\hline 10 & Specific gravity test for LECA & 0.44 & - \\
\hline 11 & Water absorption test for C.A & $1.11 \%$ & $<5 \%$ \\
\hline 12 & Sieve analysis of C.A & FM=7.27 & $6.6-8.0$ \\
\hline 13 & Impact test of C.A & $\begin{array}{l}\text { not }>45 \% \text { for concrete other than wearing } \\
\text { surface per IS 283-1970 }\end{array}$ \\
\hline
\end{tabular}


International Journal of Advances in Scientific Research and Engineering (ijasre), Vol 4 (7), July - 2018

The tests are conducted to drive an accurate mix design and for studying the properties of Expanded clay aggregate. The water absorption of LECA lightweight aggregate seems to very low and the specific gravity tests results indicate the range of light weight property. The impact value is not very high in comparison with normal aggregate but within limit.

\section{CUBE COMPRESSIVE AND SPLIT TENSILE STRENGTH TEST RESULTS}

The compressive strength and cylinder split tensile strength results of LWCA,s are comparatively less than the control mix. It is found that, the strength of the concrete decreases with the increase in LECA as a coarse aggregate.

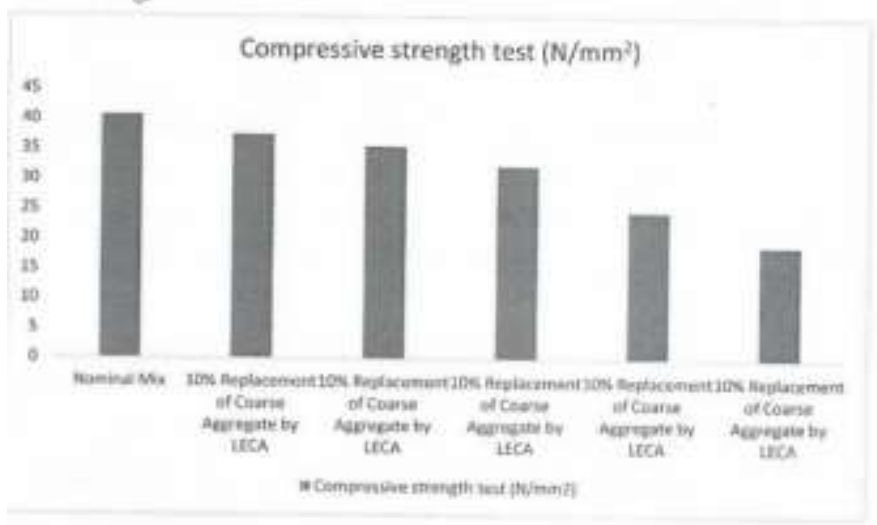

Figure 5 Compressive Strength Result

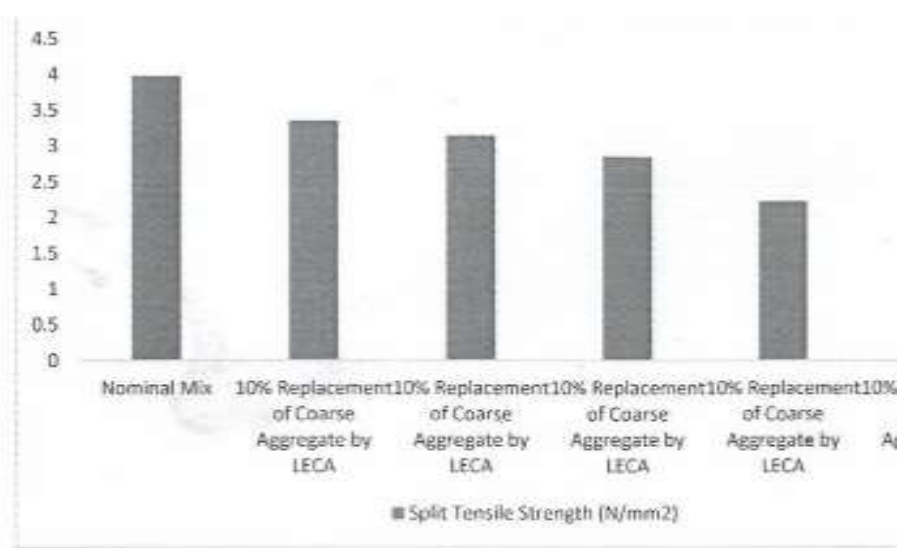

Figure 6. Split tensile Strength Result

\section{LOAD DEFLECTION BEHAVIOUR:}

The load deflection behaviors of slabs are interpreted based on plotted load vs deflection graph as shown.

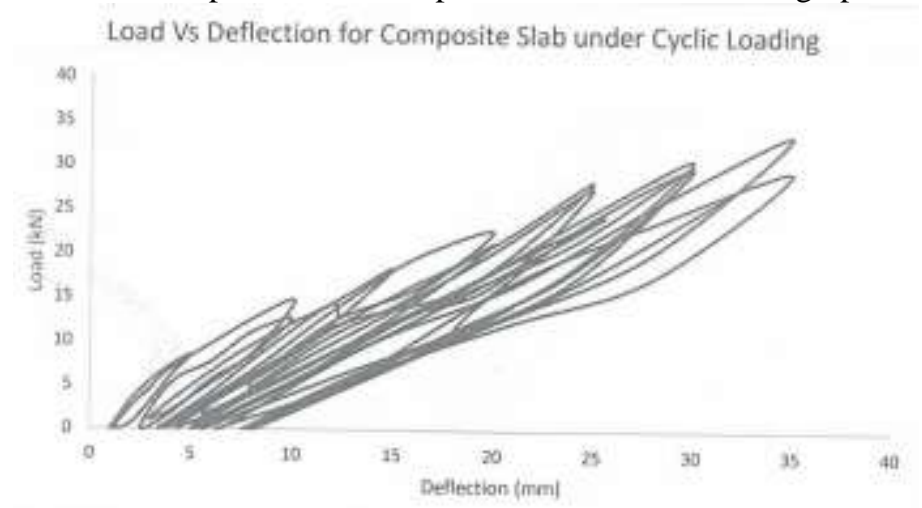

Fig 6 Load Deflection Curve for Composite Slab Under Cyclic Loading

\section{ANALYTICAL STUDY:}

The cyclic loading applied to the composite slab is validated analytically using various software such as ANSYS, ABAQUS and COMFLOR. In the analysis the COMFLOR software is used.

The COMFLOR software is developed by the TATA steels for the analysis, especially for the behavior of composite slabs under static and cyclic loadings. The softwares are developed based on the two major codal provision such as Eurocode 4 and BS 5950 . 


\section{R. Aisswarya et. al., Experimental analysis of light weight concrete}

The m-k method and partial shear connection method are the two method are designed in this software. The COMFLOR software V9.0 IS developed by TATA steel for the analysis of profiled steel sheeting composite deck slabs under static and cyclic loading. The designs are checked for Construction stage, composite stage, fire and serviceability check. The deflection limit is used under EC4 and BS 5950 codal provisions.

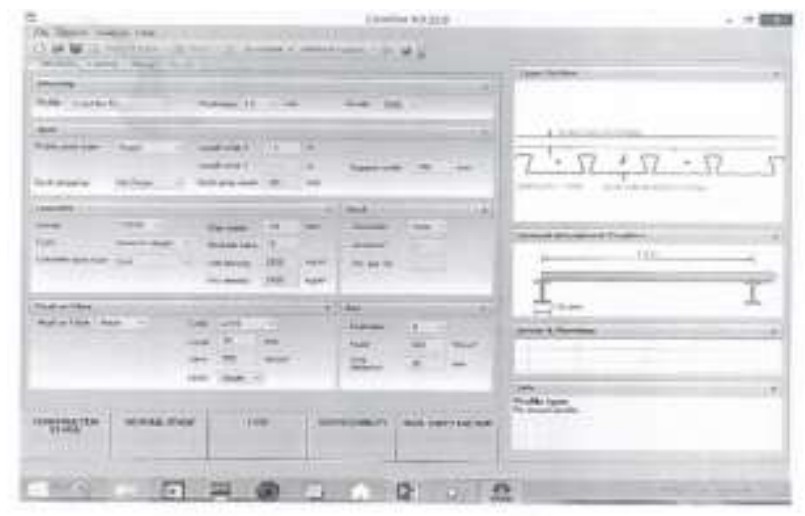

Fig 7 COMFLOR Software Display for profile type

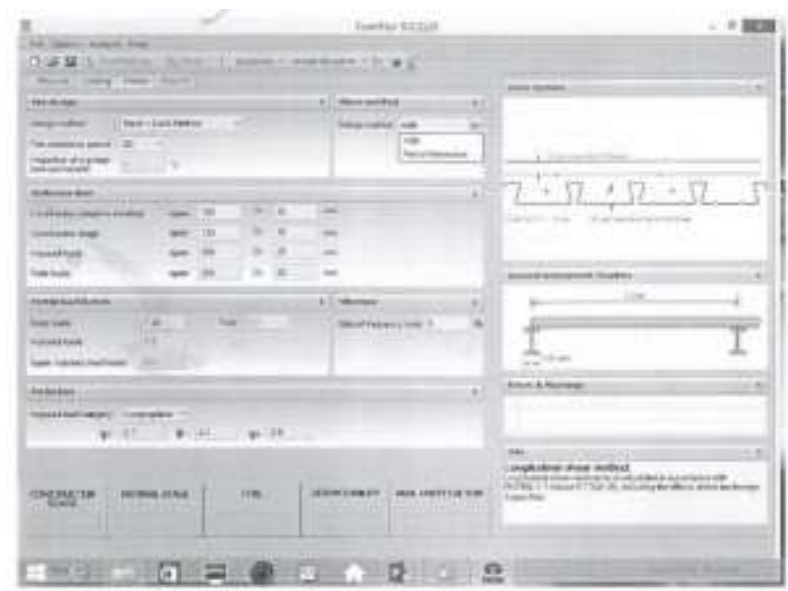

Fig 8 Longitudinal Shear Method COMFLOR Software

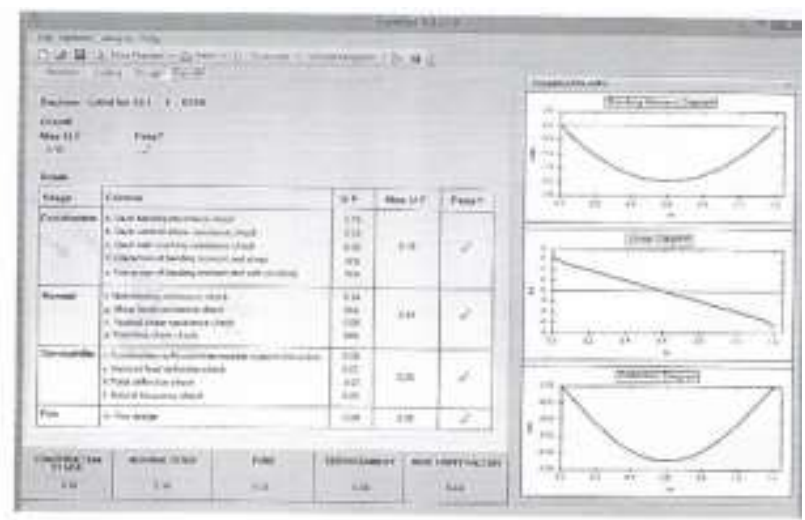

Figure 9. BMD, Shear force and Deflection Diagram

\section{CONCLUSION}

1. Structural light weight concrete can be developed by full replacement of $20 \mathrm{~mm}$ lightweight LECA coarse aggregate in M25 grade control mix.

2. The materials test result on water absorption of LECA aggregate and trail concrete cube specimen prepared indicates the necessity of pre wetting of LECA aggregate prior to concreting to compensate the high water absorption.

3. The reinforced structural light weight concrete composite slabs tested under cyclic has reasonable and comparable ultimate load capacity with control composite slabs.

4. The initial cracking load observed and ductility factor calculated indicates the better performance of light weight concrete.

5. The stiffness degradation study indicates that LWC slabs have lesser stiffness than control composite slabs. 
6. The energy absorption capacity of light weight concrete composite slabs are much lower than concrete slabs throughout the entire cycles. This is due to lesser strength properties of concrete.

7. When comparing ultimate flexural capacity of LWC and control concrete composite slabs, LWC composite beams have reasonable flexural capacity.

\section{REFERENCES}

1. Fakir Altun, Bekir Aktas, Investigation of Reinforced Concrete Slab behaviour of steel fiber added light weight concrete, Construction and Building Materials, Vol-38, 2013.

2. Zahir kuhail, Samir Shihada, Mechanical Properties of Polystyrene Light weight concrete, Journal of the Islamic University of Gaza, Vol 11, No 2, 2003.

3. Akmaluddin, Effect of tensile reinforcement ratio on the Effect of Moment of Inertia of Reinforced Concrete beam for Short term deflection calculation, Vol 43. No 3, ITB Journal of Engineering Sciences, 2011.

4. Aamer Najim Abbas, Experimental Study on Reactive powder and normal concrete rectangular beams under different loading rates, International Journal of Engineering and Advanced Technology Structures, Vol 2, No 2, June 2014.

5. Pawade Prashanth Y, Nagarnaik.P.K, Influence of silica fume in enhancement of flexural strength of steel fibre concrete and their relationship, International Journal of Civil and Structural Engineering, Vol 2, No 1, 2011.

6. S.Agus, B.Ismail and S.Amirkhan, The performance Evaluation of Light weight Concrete plies on UTHM's soft soils under static and dynamic loading tests, International Journal of Intergrated Engineering, 2010.

7. Vishwas P.Kulkarani, Sanjay Kumar B, Gaikwad, Comparative study on coconut shell aggregate with conventional concrete, International Journal of Engineering and Innovative Technology, Vol 2, Issue 12, June 2013.

8. Q.L.Yu, P.Spiesz, Development of Cement based light weight composites-mix design methodology and Hardened properties, Cement and Concrete Composites, Vol 44, 2013.

9. IS 12269-1987 Indian Standard Specification for 53 grade ordinary Portland cement (first reprint1993), Bureau of Indian Standards, New Delhi.

10. IS 383-1970 Indian Standard Specification for coarse and fine aggregate from natural sources for concrete (second revision), Bureau of Indian Standards, New Delhi.

11. IS 2386(part 1): 1963 Indian Standard Methods of test for aggregate for concrete part 1particle size and shape(Eleventh Reprint), Bureau of Indian Standards, New Delhi.

12. IS 2386(part III): 1963 Indian Standard Methods of test for aggregate for concrete part III specific gravity,Density, voids,Absorption and Bulking(Eighth reprint March 1997), Bureau of Indian Standards, New Delhi.

13. IS 10262-2009, Indian Standard concrete mix proportioning -Guidelines(first Revision), Bureau of Indian Standards, New Delhi.

14. IS 456-2000, Indian Standard plain an reinforced concrete-code of practice(Fourth edition), Bureau of Indian Standards, New Delhi. 